DOI: 10.34015/2523-4552.2021.1.05

УДК 343.81

Буряк К. М.,

кандидат юридичних наук, асистент кафедри європейського та міжнародного права Дніпровського національного університету імені Олеся Гончара

ORCID: 0000-0001-6265-9706

\title{
СПІВВІДНОШЕННЯ КАТУВАННЯ ТА ДОМАШНЬОГО НАСИЛЬСТВА
}

У статті досліджено поняття катування на міжнародному та національному рівні. Визначено спільні риси, які характерні для катування та домашнього насильства. Зазначені складнощі при кваліфікації катування та домашнього насильства: важко виміряти шкоду, завдану психіці людини; наслідки психологічного насильства складно співставити за часовими рамками; висока латентність домашньої злочинності; емоційна реакціях деяких потерпілих, через яку складно встановити реальну картину подій, збирати докази, призначати експертизи.

Ключові слова: катування; домашнє насильство; психологічне насильство; кваліфікація.

В статье исследовано понятие пытки на международном и национальном уровне. Определены общие черты, характерные для пыток и домашнего насилия. Указаны сложности при квалификации пыток и домашнего насилия: трудно измерить ущерб, нанесенный психике человека; последствия психологического насилия сложно сопоставить по временным рамкам; высокая латентность домашней преступности; эмоциональная реакциях некоторых пострадавших, по которой сложно установить реальную картину событий, собирать доказательства, назначать экспертизы.

Ключевые слова: пытки; домашнее насилие; психологическое насилие; квалификация.

Постановка проблеми. Останнім часом домашня злочинність набуває резонансу у суспільстві. Все частіше фіксуються звернення до поліції та втручання правоохоронних органів у врегулювання сімейних конфліктів, які супроводжуються насильницькими діяннями. Проте, в деяких випадках домашнє насильство, як вид кримінального правопорушення передбаченого ст. 126-1 КК
України характеризується особливою жорстокістю, як фізичного, так і психологічного характеру. 3 огляду на це, ми розглядаємо сам факт катування дружини, дитини або інших членів родини, як суспільнонебезпечне явище, що передбачає настання кримінальної відповідальності за ст. 127 КК України.

Водночас, аналізуючи чинне законодавство, емпіричний матеріал 
та фахову юридичну літературу відповідь щодо співвідношення катування та домашнього насильства в кримінологічні науці не можливо отримати, оскільки наукових праць присвячених саме співвідношення катування і домашнього насильства на при великий жаль, не достатньо. Що і спонукало нас підготувати дану статтю.

Постановка завдання. У цій статті ми спробуємо виявити спільні та відмінні рис катування та домашнього насильства, як видів кримінальних правопорушень, що вчиняються в домашній сфері у розрізі предмету нашого дослідження.

Аналіз останніх досліджень і публікацій. Проблема співвідношення катування і домашнього насильства була предметом вивчення таких вітчизняних вчених: А. Б. Благої, O. І. Бєлової, І Г. Богатирьова, О. В. Бойко, Б. М. Головкіна, О. М. Джужі, О. І. Зазимко, О. В. Ковальової, О. Д. Коломойця, Л. В. Крижної, М. Г. Кузнєцова, А. В. Савченка, M. I. Хавронюка, А. О. Червяцова, П. В. Пушкар Н. В. Лесько, С. В. Романцевої, М. Ю. Самченко та зарубіжних вчених А.А. Ахматова, Г. М. Іляшенка, Д. О. Корецького, Г. М. Міньковського, В. П. Мелешко, О. В. Старкова, Д. О.Шестакова та інших.

Однак, на сьогодні серед науковців не вироблено єдиного підходу до співвідношення цих двох видів кримінальних правопорушень, що вчиняються в домашні сфері у розрізі виконання завдань, які поставлені перед підрозділами Національної поліції України щодо запобігання вчинення кримінального правопорушення у виді катування або домашнього насильства.
Виклад основного матеріалу. Розглядаючи катування та домашнє насильство, як видів кримінальних правопорушень, що вчиняються в домашній сфері ми вважаємо за доцільне розглянути термін «катування» який знайшов своє відображення у низці міжнародних та вітчизняних нормативно-правових актів. Так, стаття 5 Загальної декларації з прав людини 1948 року визначає: «Ніхто не повинен зазнавати тортур, або жорстокого, нелюдського, або такого, що принижує його гідність, поводження і покарання» [1].

Стаття 3 Європейської конвенції про захист прав людини і основоположних свобод 1950 р. : «Нікого не може бути піддано катуванню або нелюдському чи такому, що принижує гідність поводженню або покаранню»[2]. Частина 2 статті 5 Американської конвенція про права людини 1969 року: «Ніхто не може зазнавати тортур, жорстокого, нелюдського чи такого, що принижує гідність покарання або поводження» [3].

Відповідно до статті 1 Конвенції ООН проти катувань або нелюдського чи такого, що принижує гідність, поводження або покарання 1984 року «катування означає будьяку дію, якою будь-якій особі навмисне заподіюються сильний біль або страждання, фізичне чи моральне, щоб отримати від неї або від третьої особи відомості чи визнання, покарати їі за дії, які вчинила вона або третя особа чи у вчиненні яких вона підозрюється, а також залякати чи примусити ії або третю особу, чи з будь-якої причини, що грунтується на дискримінації будьякого виду, коли такий біль або страждання заподіюються держав- 
ними посадовими особами чи іншими особами, які виступають як офіційні, чи з їх підбурювання, чи 3 їх відома, чи за їх мовчазної згоди. В цей термін не включаються біль або страждання, що виникли внаслідок лише законних санкцій, невіддільні від цих санкцій чи спричиняються ними випадково» [4].

Положення про заборону катування регулюються також Африканська Хартія прав людини і народів (стаття 5); Американська декларація прав і обов'язків людини (стаття 27); Арабська Хартія прав людини (стаття 8); Каїрська Декларація прав людини в ісламі (статті 19-20); Паризька Хартія для нової Європи (НБСЕ); Конвенція про захист прав всіх трудящих-мігрантів та членів їх сімей (стаття 10); Конвенція про права дитини (стаття 37); Європейська Конвенція про запобігання тортурам та нелюдському або такому, що принижує гідність, поводженню чи покаранню; Міжамериканська Конвенція щодо попередження та покарання за тортури; Міжнародний пакт про громадянські та політичні права (статті 4, 7, 10); Мінімальні стандартні правила ООН поводження 3 в'язнями (стаття 31); Римський статут Міжнародного кримінального суду та інші.

У національному законодавстві питання катування регулюється ст. 28 Конституції України: «Кожен має право на повагу до його гідності. Ніхто не може бути підданий катуванню, жорстокому, нелюдському або такому, що принижує його гідність, поводженню чи покаранню. Жодна людина без її вільної згоди не може бути піддана медичним, науковим чи іншим дослідам» [5].

В ч. 1 ст. 127 Кримінального кодексу України (КК України) катування визначено як «умисне заподіяння сильного фізичного болю або фізичного чи морального страждання шляхом нанесення побоїв, мучення або інших насильницьких дій з метою примусити потерпілого чи іншу особу вчинити дії, що суперечать їх волі, у тому числі отримати від нього або іншої особи відомості чи визнання, або з метою покарати його чи іншу особу за дії, скоєні ним або іншою особою чи у скоєнні яких він або інша особа підозрюється, а також з метою залякування чи дискримінації його або інших осіб» [6].

Потрібно відзначити, що кримінальна характеристика «катування» має відмінності у міжнародному та національному законодавстві. Якщо порівняти Конвенцію про захист прав і основоположних свобод зі ст. 127 КК України, то можна звернути увагу на те, що елементи складу злочину за ст. 127 КК України мають більш широкий спектр, ніж у Європейській конвенції. Це дозволяє здійснити подальше порівняння діянь, які підпадають під катування та домашню злочинність (див. табл. 1). 


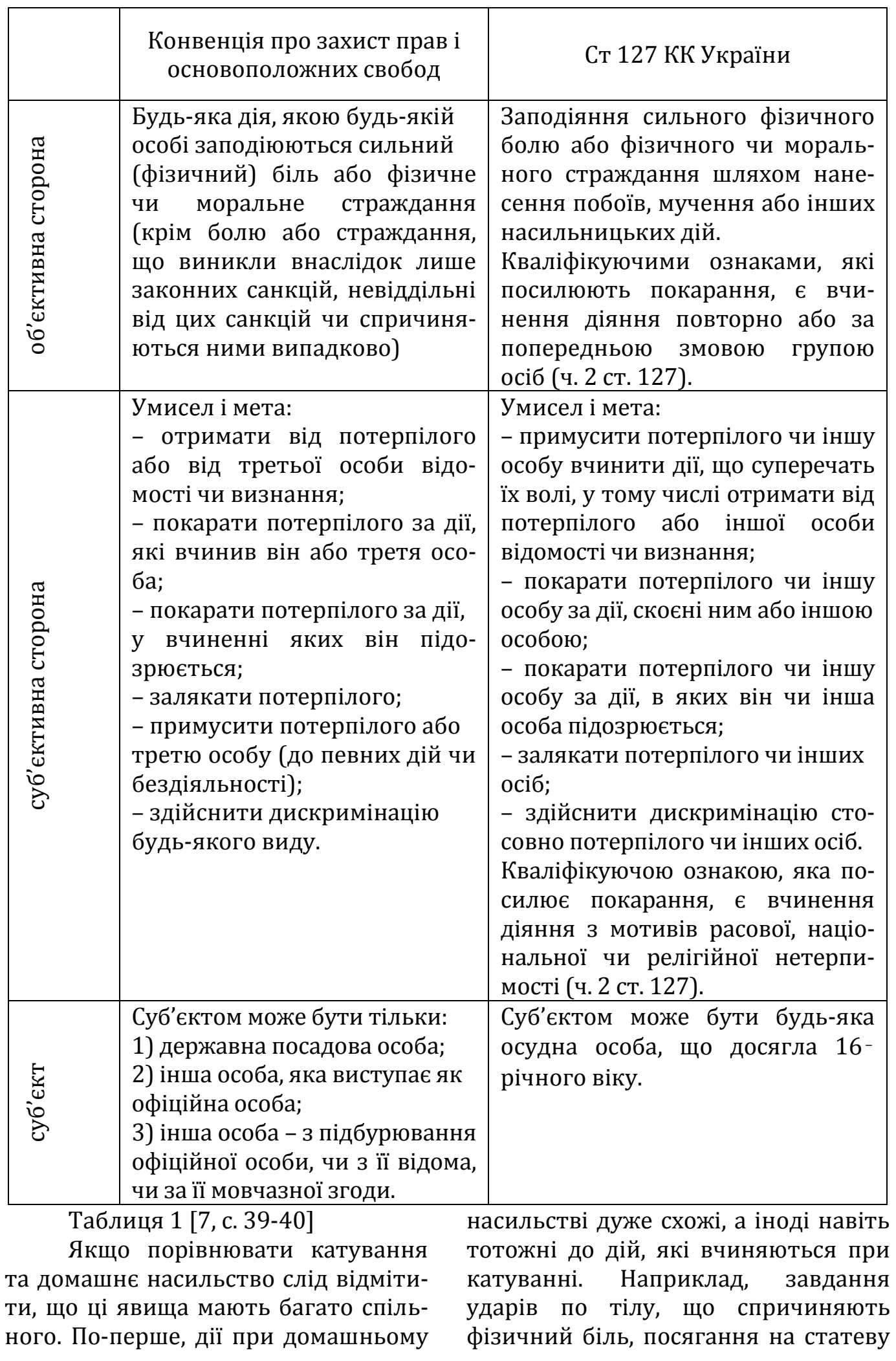


недоторканість особи, придушування. Вищеперераховані дії завжди супроводжуються сильним стресом, почуттям страху та здатні принизити особу, зламати їі морально. Подруге, в кожному із випадків обов'язково настають наслідки у формі сильного фізичного болю та/або жорстокого морального страждання. По-третє, в обох випадках наявні суб'єкти-агресори, які 3 метою досягнення своєї мети вчиняють щодо іншої особи дії у формі вербального, фізичного чи емоційного знущання. По-четверте, і суб'єкт домашнього насильства, i суб'єкт катування усвідомлюють, що їхні дії не відповідають загальноприйнятим у суспільстві правилам поведінки, $\epsilon$ навмисними, цілеспрямованими та суспільно небезпечними. Можна стверджувати, що домашнє насильство фактично може переростати у катування із наявністю усіх ознак складу цього злочину.

Складність

розмежування діянь домашнього насильства і катування, а саме психологічного катування, полягає у тому, що важко зафіксувати та виміряти шкоду, завдану психіці людини. Психологічне насильство $\epsilon$ достатньо складним явищем в правовому полі. Вітчизняна та міжнародна практика свідчать про те, психологічне насильство у більшості випадків поєднане 3 фізичним або сексуальним. Через це при здійсненні кваліфікації йому не надають самостійності, а розглядають як додатковий елемент фізичного, економічного або сексуального насильства. Проте за умови надання самостійності такому виду насильства можна було б здійснити його співрозмірність за різними складами злочинів.
Складність визначення психологічного насильства обумовлена тим, що його важко визначити. Наприклад, особа, яка проживала в сім'ї, в якій мало місце домашнє насильство, вона може не усвідомлювати його прояви у власній новій сім'ї та підкорюватися тиранічному партнеру. Наслідки психологічного насильства важко співставити за часовими рамками. Більшість психічних хвороб, які стали наслідком психологічного тиску проявляються не відразу, натомість тілесні ушкодження можна зафіксувати одразу після вчинення насильства. Ці умови створили колізію у національному законодавстві стосовно регулювання та призначення покарання за психологічне насильство. Лише у 2018 році Закон України «Про запобігання та протидію домашньому насильству» [8] вперше окреслив психологічну складову у сфері домашнього насильства.

Відсутність дієвого інструменту регулювання діянь, які супроводжуються психологічним насильством, пов'язано з високою латентність домашньої злочинності, що пов'язано 3 замовчування такого виду злочинів або не бажанням особи повертатися до травмуючих подій і разом 3 тим призводить до знецінення даної проблеми в рамках законодавчого регулювання. Проте, психологічне насильство, яке відбувається у сім'ї не може розглядатись як особисте діло кожної окремої родини, тому що його безкарність породжує розвиток злочинності в цілому та прогалини в правовому регулюванні.

Ще однією складністю кваліфікації діянь, які будуть підпадати під катування чи домашнє насильство $\epsilon$ емоційна реакціях де- 
яких потерпілих, через яку складно встановити реальну картину подій збирати докази, призначати експертизи. В процесуальному аспекті важко і належним чином задіяти інститут свідків, які могли б послугувати третьою стороною у встановленні якісного розмежування катування та домашнього насильства. Все це негативно позначається на судовій практиці.

На прикладі матеріалів справи № 359/3382/20, засуджений вчиняв систематичні активні дії психологічного насильства відносно своєї дружини, з якою він проживає в одному помешканні, що виражалися у словесній образі, приниженні, переслідування, залякуванні та були спрямовані на обмеження волевиявлення потерпілої і її нездатність захистити себе.

В наслідок чого завдана шкода психічному здоров`ю потерпілої. Це призвело до моральних страждань останньої, погіршило якість їі життя, знайшло відображення у затяжній особистісній фрустрації та сформованій життєвій кризі, які пов`язані $з$ перманентним відчуттям зневіри у власній силі, зневірі у майбутньому, безпорадності, що $\epsilon$ наслідком три- валого переживання. Насильницькі дії психологічного характеру вчинялися неодноразово та зафіксовані працівниками поліції [9].

На нашу думку, виходячи 3 тяжких наслідків психологічного характеру, яких зазнала потерпіла, доречно було б інкримінувати засудженому катування за ст. 127 КК України.

Висновки та пропозиції. На підставі вищевикладеного робимо висновок, що катування і домашнє насильство має різні види, а саме фізичне, економічне, сексуальне, психологічне. Проте останнім часом спостерігаються випадки вкрай жорстоких діянь у сімейній сфері, що підтверджує нашу позицію віднести катування до різновидів домашньої злочинності. Вбачаємо доцільним співвідносити вчинення особою домашнього насилля та катування, як суспільно-небезпечного явища, що вчиняється в домашній сфері. Найбільш характерною рисою катування $є$ особливий відтінок жорстокості, властивий лише навмисному, нелюдському поводженню, яке завдає серйозних страждань, в тому числі психологічного характеру.

\section{Список використаних джерел}

1. Загальна декларація прав людини : Міжнародний договір України від 10 грудня 1948 p. URL:https://zakon.rada.gov.ua/laws/show/995_015\#Text (дата звернення: 26.03.2021).

2. Європейської конвенції про захист прав людини і основоположних свобод: Міжнародний договір України від 04 листопада 1950 p. URL: https://zakon.rada.gov.ua/laws/show/995_004\#Text (дата звернення: 26.03.2021).

3. American Convention on Human Rights on 22 November 1969. URL: https://treaties.un.org/doc/publication/unts/volume\%201144/volume-1144-i-17955english.pdf (дата звернення: 26.03.2021).

4. Конвенція проти катувань та інших жорстоких, нелюдських або таких, що принижують гідність, видів поводження і покарання: Міжнародний договір України від 26 січня 1987 p. URL: https://zakon.rada.gov.ua/laws/show/995_085\#Text (дата звернення: 26.03.2021). 
5. Конституція України : Закон України від 28 черв. 1996 р. № 254к/96-ВР. URL: https://zakon.rada.gov.ua/laws/show/254\%D0\%BA/96-\%D0\%B2\%D1\%80\#Text (дата звернення: 26.03.2021).

6. Кримінальний Кодекс України : Закон України від 05.04.2001. URL: https://zakon.rada.gov.ua/laws/show/2341-14\#Text (дата звернення: 26.03.2021).

7. Науково-практичний коментар Законодавство України проти катувань та інших жорстоких, нелюдських або таких, що принижують гідність, видів поводження і покарання / За ред. М. І. Хавронюка, В. О. Гацелюка. Київ : ВАITЕ, 2014. 320 с.

8. Про запобігання та протидію домашньому насильству: Закон України від 07.12.2017 р. №2229-VIII. URL: https://zakon.rada.gov.ua/laws/show/2229-19\#Tеxt (дата звернення: 26.03.2021).

9. Вирок Бориспільського міськрайонного суду Київської області від 06 липня 2020 р. (Справа № 359/3382/20, Провадження № 1-кп/359/501/2020). URL: https://reyestr.court.gov.ua/Review/90267326 (дата звернення: 26.03.2021).

\section{References}

Havronyuk, M. I., Gacelyuk, V. O. (red.). (2014). Naukovo-praktichnij komentar Zakonodavstvo Ukrayini proti katuvan ta inshih zhorstokih, nelyudskih abo takih, sho prinizhuyut gidnist, vidiv povodzhennya i pokarannya. Kiyiv: VAITE.

K. Buriak, Candidate of Legal Sciences, Assistant of the Department of European and International Law of Oles Honchar Dnipro National University

ORCID: 0000-0001-6265-9706

\section{Correlation between torture and domestic violence}

The concept of torture at the international and national levels was examined in the article. The criminal characterization of «torture» differs in international and national legislation. If we compare the Convention for the protection of rights and fundamental freedoms with Article 127 of the Criminal Code of Ukraine, we can draw attention to the fact that the elements of crime under Article 127 of the Criminal Code of Ukraine have a wider range than in the European Convention. Common features, which are characteristic of torture and domestic violence are identified. Firstly, acts of domestic violence are very similar and sometimes even identical, to acts of torture. For example, blows to the body, which cause physical pain, encroachment on the sexual integrity of the person, suppression. The above actions are always accompanied by severe stress, a sense of fear and can humiliate a person, break her morally. Secondly, in each of the cases, there are necessarily consequences in the form of severe physical pain and/or severe moral suffering. Thirdly, in both cases, there are aggressor subjects who, in order to achieve their goal, commit actions in the form of verbal, physical or emotional bullying against another person. Fourthly, both the subject of domestic violence and the subject of torture are aware that their actions do not comply with the generally accepted rules of behavior in society, are deliberate, purposeful and socially dangerous. It can be argued that domestic violence can actually escalate into torture with all the signs of this crime. Difficulties in qualifying torture and domestic violence are indicated. It is difficult to notice and measure the damage caused to the human psyche. When per- 
forming a qualification, psychological violence is not given independence, but is considered as an additional element of physical, economic or sexual violence. The consequences of psychological violence are difficult to compare over time. Another difficulty in qualification is the emotional reaction of some victims, which makes it difficult to establish the real picture of events, collect evidence, and appoint expert examinations.

Keywords: torture; domestic violence; psychological violence; qualification. 